\title{
A RESPONSABILIDADE DO CIRURGIÃO GERAL NAS EQUIPES QUE ATENDEM EMERGÊNCIA
}

\section{THE GENERAL SURGEON'S LIABILITY AT THE EMERGENCY CARE TEAM}

\author{
Guilherme Eurico Bastos da Cunha, ECBC-RJ \\ Ex-Presidente do Colégio Brasileiro de Cirurgiões
}

Nos últimos dez anos, com freqüência, temos presenciado, analisado e emitido opinião sobre o futuro do Cirurgião Geral. A velocidade da evolução tecnológica atingiu frontalmente a formação do médico e o leque de opções nas especialidades torna-se cada vez mais diverso, inclusive nas mesmas áreas conexas. $\mathrm{O}$ médico recém-formado tem freqüentemente sua orientação enfocada no binômio especialização e retorno econômico- financeiro, fazendo uma hilação, nem sempre correta, de que se não fizer uma especialização hermética, terá dificuldades em colher os frutos financeiros da profissão médica, o que ocorreria se fizesse uma opção mais generalista. Nossos médicos, formados entre 10 e 15 anos, com freqüência fazem coro a esta situação.

Não é incomum tomarmos conhecimento de crianças, por exemplo, que atendidas no Serviço de Emergência, são transferidos para outros hospitais, porque no primeiro atendimento não havia de plantão, cirurgiões pediátricos. Em outras ocasiões, pacientes deixam de ter o hemitórax drenado para aliviar um hemopneumotórax de origem traumática, por não haver cirurgião de tórax na equipe de emergência. Situações semelhantes envolvem, ainda, pacientes com doenças gineco-obstétricas, urinárias obstrutivas e a mais grave de todas, os episódios de parada cardíaca, em ato operatório ou em enfermidades próprias do coração que atingem o enfermo em sua atividade diária.

Se analisarmos suas origens, notamos que até os anos 60 do século passado, o cirurgião geral, atendia aos traumatismos osteo-articulares, fazia cirurgia torácica, primeiro a pulmonar, depois a cardíaca. Foi ele ainda pioneiro na cirurgia do esôfago, da hipertensão porta e das enfermidades cirúrgicas da cavidade abdominal, do aparelho digestivo e glândulas anexas, e também do aparelho gênito-urinário. Nos membros inferiores o cirurgião geral tratava dos tumores de partes moles e das enfermidades arteriais e venosas. No pescoço tratava as mal formações congênitas abordáveis pela cirurgia, as doenças tumorais da região e as enfermidades da tireóide e paratireóides.

Convenhamos que este é um vasto espectro de ação para o cirurgião geral, e que o crescimento da informação científica e o progresso tecnológico propriamente dito vieram pouco a pouco a desmembrar a "Província da Cirurgia Geral" com diria o Professor Salomão Kaiser. A ortopedia e traumatologia, a neurocirurgia, a urologia, a ginecologia e obstetrícia, foram as primeiras a separarem-se da cirurgia geral. Mais tarde a cirurgia cardio- vascular, a pleuro-pulmonar, a cirurgia pediátrica, a cirurgia endócrina, a cirurgia plástica e outros ramos, progressivamente foram deixando a cirurgia geral, chegando até a super especialidades como a cirurgia da mão.

Se no domínio da cirurgia eletiva é relativamente fácil encaminhar pacientes para um especialista, o mesmo não acontece quando analisamos a problemática enfrentada na cirurgia de urgência. O politraumatismo atinge indistintamente adultos e crianças, homens e mulheres e a todas as raças, de modo democrático, e exige das equipes que trabalham na emergência dos hospitais um amplo domínio e capacidade resolutiva de atender as exigências básicas da emergência: asfixia, hemorragias e a parada cardíaca. Para esse mister é necessário um modelo de cirurgião geral que há muito foi definido pelo Colégio Brasileiro de Cirurgiões e que se faz necessário nos Serviços de Emergência. Algumas Escolas de Medicina como a da Universidade de São Paulo e a da Universidade Federal Fluminense, possuem disciplina de cirurgia de urgência em seus currículos, procurando formar cirurgiões capacitados a este difícil tipo de atendimento. Este modelo de cirurgião tem que ser capaz também de solucionar, de modo adequado, as enfermidades definidas como situações de urgências que são, por exemplo, as peritonites, as hemorragias intra-peritoniais, do sistema digestório e intra-torácicas, as obstruções intestinais, gênito-urinárias e as enfermidades arteriais periféricas e venosas agudas. Estas lesões podem atingir adultos e crianças e são de responsabilidade do cirurgião geral, membro da equipe de emergência desses hospitais e máxime quando são lotados como chefes de equipe.

Embora alguns poucos grandes hospitais no Brasil possam dispor de cirurgiões especializados em suas equipes de plantão ou alcançáveis, este exemplo não autoriza a generalizarmos a idéia de que o cirurgião geral da equipe de plantão esteja liberado de ter a responsabilidade de atuar seguindo os preceitos emitidos pelo Colégio Brasileiro de Cirurgiões.

Em vista do exposto ainda é impossível, na maior parte do território nacional, abrirmos mão de um cirurgião que seja capaz de solucionar todas as emergências, resolver eficientemente a maioria das doenças que necessitam tratamento cirúrgico de urgência, quer estejam no tórax, no abdômen ou nos membros, e saber realizar os primeiros socorros, reconhecendo o diagnóstico básico destas lesões, fazendo atendimento primário e sabendo removê-los para hospitais adequados a tratá-los. É, pois, inadmissível, que grandes hospitais que atendem urgência, terem pacientes adultos ou crianças transferidos destes serviços para outros a título de não disporem em suas equipes de cirurgiões especializados para solucionar aquelas situações. 